\title{
PARTICULARITIES OF CONSUMER BEHAVIOR IN THE COSMETICS MARKET
}

\author{
Eugenia Harja \\ "Vasile Alecsandri” University of Bacau \\ eugenia.harja@ub.ro \\ Laura Cătălina Timiras \\ "Vasile Alecsandri" University of Bacau \\ timiras.laura@ub.ro
}

\begin{abstract}
Based on some results of a research organized in the county of Bacau on consumers of cosmetics, using the questionnaire, this article analyses a number of issues with regard to consumer behavior, namely: cosmetics brand most commonly purchased by consumers, cosmetics category to which are allocated the largest sums of money, the amounts of money that consumers are willing to spend per month to purchase these types of products, the importance of some of the main criteria considered when buying cosmetic products and differences manifested in categories of respondents by a number of variables such as age, sex, marital status, income and living environment. The research was conducted using a sample of 500 respondents non-randomly selected, so that the results presented refer only to the studied sample, being a guide to community from which it was extracted.
\end{abstract}

\section{Keywords}

cosmetics; consumer behavior; brand; product selection criteria; expenses for cosmetics

\section{JEL Classification}

M31

\section{Introduction}

During March-April 2014, in the county of Bacau, we organized a direct research, using the questionnaire, in order to know the particularities of consumer behavior for cosmetics. The research was exploratory, the obtained results being a guide for reference in Bacău market, given that the determination of the investigated sample (size and selection process) did not respect the principles of the theory of the survey. Some of the objectives pursued through this research and to which we referred in the article were: knowledge of the cosmetics brand acquired by most of shoppers, identifying the categories of cosmetics for which the consumers allocate the largest sums of money, knowledge of the amount of money that a consumer is willing to spend per month to purchase these products, determining the importance of some of the main criteria for assessing the products in purchasing decision-making process, and the extent to which variables such as age, sex, marital status, income and environment influence the issues outlined above.

The community studied was the population over 15 years. We used the snowball sampling, the questionnaires being administrated by interviewers. Investigated sample of 500 people, represented the different categories of persons in terms of age (except those under 15, these are not undertaken under study), gender, living environment, income or marital status. 


\section{Research results}

Referring to cosmetics brand most frequently purchased by investigated persons, of the 500 respondents, 28 did not provide information on this topic (indicated response option "do not know / no answer" in the questionnaire). The results presented below refer only to the 472 respondents who said what brand of cosmetics purchase most often. Thus, from this point of view, Avon ranks first with a share of over $60 \%$ of those who said they most often purchase this brand. The second place, but at a considerable distance (15\% of total respondents) stands Oriflame, a brand comparable to first one in terms of specific distribution system (through direct sales), followed by Nivea, L'Oreal, Adidas and Farmec. 3.6\% of respondents stated that acquires most common "other brand". For the category "other brand" respondents indicated: Puma ( $0.6 \%$ of consumers) and Faberlic, Yves Rocher, Dolce \& Gabana, Amway, Chanel, Christian Dior, Fa, Gerocossen, Gucci, No.7., Versace, each of these being indicated by less than $0.5 \%$ of consumers.

For the categories of persons by various socio-economic and demographic criteria, we found a number of differences concerning cosmetic brand most often purchased as follows:

- By age groups, Avon is preferred to a greater extent by people over 20 years (and especially over 30 years), while Nivea and Adidas are preferred to a greater extent by the very young (15-20 years) compared with other age groups. L'Oreal and Oriflame brands were only given by the category over 20 years and Farmec by those over 30;

- By gender, Avon products are preferred to a greater extent by women than men, while a higher proportion of men (compared to women) use most often: Oriflame, Nivea, L'Oreal, Adidas;

- Depending on civil status, people living together prefer in greater extent Avon to those who live alone, while Nivea is preferred to a greater extent by those who live alone compared to those who live together;

- In terms of income, there is not an obvious influence on preferences, i.e. there is no guidance showing greater or lesser extent in buying certain brands with revenue growth;

- By residence, consumers show greater orientation towards Avon, Oriflame and Adidas in urban areas, while L'Oreal and Nivea are preferred by those in rural areas (compared to people in urban areas).

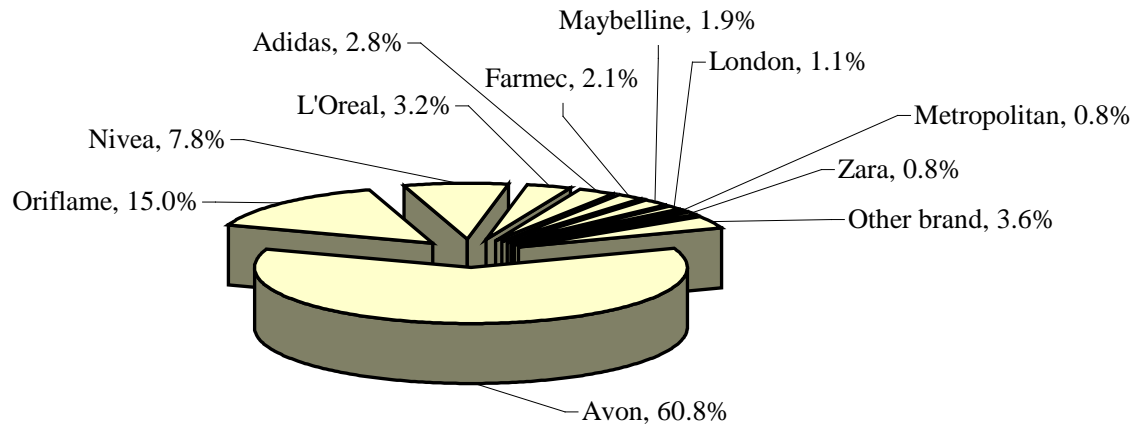

Figure 1 Structure of respondents* depending on the brand of cosmetics most frequently purchased

* were exempted respondents who did not answer 
Table 1 Structure of respondents * depending on the brand of cosmetics most frequently purchased by age, sex, marital status, income and living environment (\%)

\begin{tabular}{|c|c|c|c|c|c|c|c|c|c|}
\hline \multirow[b]{2}{*}{ Brand } & \multicolumn{5}{|c|}{ Age } & \multicolumn{2}{|c|}{ Gender } & \multicolumn{2}{|c|}{ Marital status } \\
\hline & 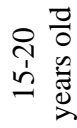 & 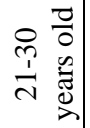 & 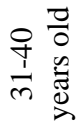 & 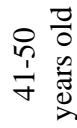 & 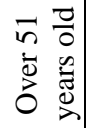 & $\frac{\mathscr{U}}{\widetilde{\Xi}}$ & $\frac{\stackrel{0}{\pi}}{\sum^{\pi}}$ & 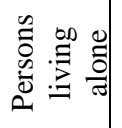 & 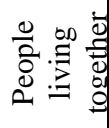 \\
\hline Avon & 27 & 41 & 67 & 63 & 55 & 81 & 46 & 51 & 64 \\
\hline Oriflame & 0 & 22 & 17 & 14 & 15 & 6 & 22 & 14 & 15 \\
\hline Nivea & 36 & 7 & 5 & 8 & 9 & 5 & 10 & 11 & 7 \\
\hline L'Oreal & 0 & 7 & 3 & 2 & 6 & 2 & 4 & 4 & 3 \\
\hline Adidas & 9 & 4 & 2 & 2 & 3 & 0 & 5 & 4 & 2 \\
\hline Farmec & 0 & 0 & 2 & 2 & 2 & 2 & 2 & 2 & 2 \\
\hline Other brand & 27 & 19 & 3 & 8 & 11 & 5 & 11 & 15 & 6 \\
\hline Total & 100 & 100 & 100 & 100 & 100 & 100 & 100 & 100 & 100 \\
\hline
\end{tabular}

Table 1 (continuation)

\begin{tabular}{|c|c|c|c|c|c|c|c|c|}
\hline \multirow[b]{2}{*}{ Brand } & \multicolumn{6}{|c|}{$\begin{array}{l}\text { The average monthly income of the household } \\
\text { (average per person) }\end{array}$} & \multicolumn{2}{|c|}{ Residence } \\
\hline & 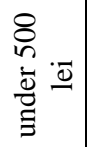 & 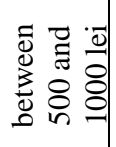 & 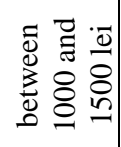 & 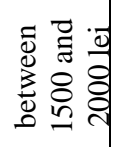 & 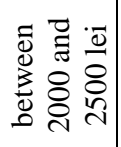 & 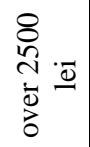 & 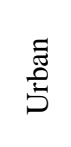 & 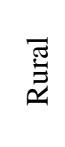 \\
\hline Avon & 61 & 56 & 54 & 52 & 54 & 68 & 67 & 59 \\
\hline Oriflame & 14 & 21 & 14 & 9 & 15 & 15 & 17 & 13 \\
\hline Nivea & 11 & 10 & 4 & 4 & 8 & 8 & 6 & 8 \\
\hline L'Oreal & 2 & 4 & 11 & 13 & 6 & 0 & 1 & 3 \\
\hline Adidas & 2 & 4 & 7 & 0 & 4 & 2 & 3 & 1 \\
\hline Farmec & 5 & 0 & 0 & 0 & 2 & 2 & 1 & 2 \\
\hline Other brand & 7 & 4 & 11 & 22 & 11 & 5 & 5 & 14 \\
\hline Total & 100 & 100 & 100 & 100 & 100 & 100 & 100 & 100 \\
\hline
\end{tabular}

Cosmetics for which investigated persons have allocated the most money were body care products (soaps, shower gels, deodorants, lotions, etc.), followed by perfumes and makeup. The smallest amount of money was allocated for skin care products (creams, cleansers, masks, shaving products, etc.) and hair care products (shampoo, conditioner, treatment, etc.). Information presented refer exclusively to the 434 respondents who provided information on this issue.

By socio-economic and demographic criteria, there is real differences between respondents in terms of product categories for which they are allocated the largest amount of money, namely:

- By age groups, it is observed that most young allocate large sums of money especially for body or hair care products, while people over 50 years for perfumes. With age there is a shift in needs so that more people allocate the largest sums of money for skin care products and fragrances at the expense of hair and body care. To makeup products are allocated the largest sums of money by people of 31-40 years; 
- By gender, more women (compared to men) allocate the largest amount of money to perfumes, followed by makeup products, while more men (than women) allocate the largest sums of money for skin, hair and body care;

- Depending on civil status, most people who live alone allocates the largest amount of money to perfumes, and most of the people living along allocate large sums to body care products;

- By income categories, it is noted that for perfume are allocated large sums of money especially by high income categories, while most people with modest incomes allocate the largest amount of money for body care products. There is an orientation following the increasing of incomes, more and more people investing in skin care products and perfumes (the largest sums of money are allocated to these categories), to the detriment of products for hair and body;

- Most of the people in urban areas allocate money for perfumes, while in rural areas, body care products are preferred.

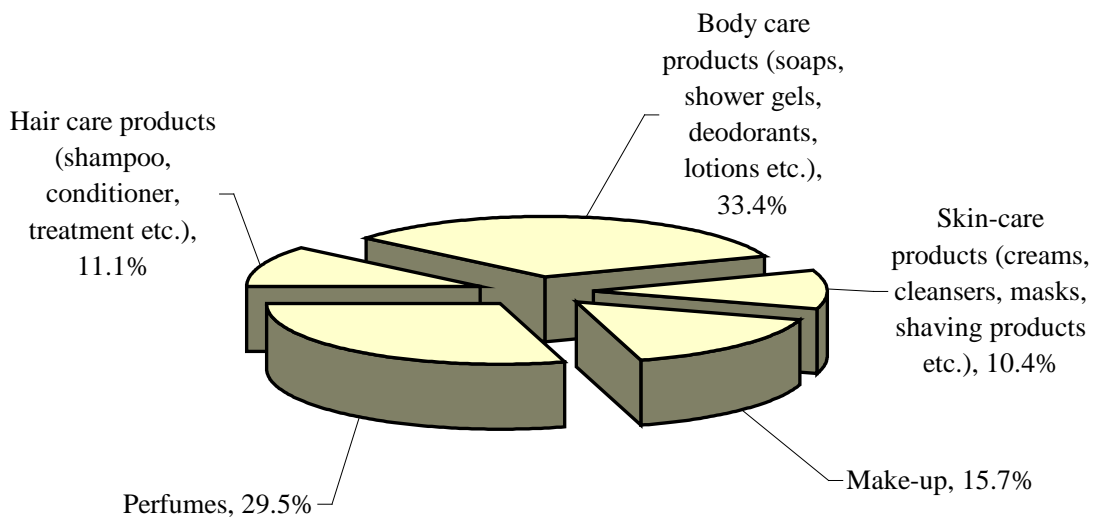

Figure 2 Structure of respondents* depending on the products to which are allocated the largest sums of money

* were exempted respondents who did not answer

Table 2 Structure of respondents * depending on the products to which are allocated the largest sums of money by age, sex, marital status, income and living environment (\%)

\begin{tabular}{|c|c|c|c|c|c|c|c|c|c|}
\hline \multirow[b]{2}{*}{ Product category } & \multicolumn{5}{|c|}{ Age } & \multicolumn{2}{|c|}{ Gender } & \multicolumn{2}{|c|}{$\begin{array}{c}\text { Marital } \\
\text { status }\end{array}$} \\
\hline & 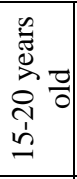 & 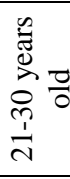 & 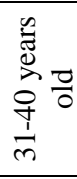 & 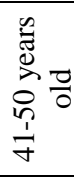 & 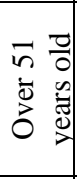 & 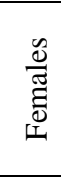 & $\frac{\stackrel{\Xi}{\pi}}{\sum_{\pi}^{\pi}}$ & 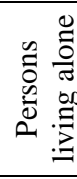 & 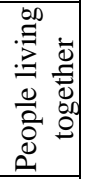 \\
\hline $\begin{array}{l}\text { Skin-care products (creams, } \\
\text { cleansers, masks, shaving products } \\
\text { etc.) }\end{array}$ & 3 & 4 & 13 & 10 & 16 & 5 & 17 & 9 & 11 \\
\hline Make-up & 3 & 6 & 35 & 11 & 13 & 29 & 0 & 27 & 10 \\
\hline Perfumes & 0 & 4 & 31 & 31 & 56 & 32 & 27 & 39 & 25 \\
\hline $\begin{array}{l}\text { Hair care products (shampoo, } \\
\text { conditioner, treatment etc.) }\end{array}$ & 29 & 40 & 10 & 3 & 6 & 5 & 18 & 9 & 12 \\
\hline $\begin{array}{l}\text { Body care products (soaps, shower } \\
\text { gels, deodorants, lotions etc.) }\end{array}$ & 65 & 46 & 13 & 46 & 9 & 29 & 38 & 16 & 41 \\
\hline Total respondents & 100 & 100 & 100 & 100 & 100 & 100 & 100 & 100 & 100 \\
\hline
\end{tabular}


Table 2 (continuation)

\begin{tabular}{|c|c|c|c|c|c|c|c|c|}
\hline \multirow[b]{2}{*}{ Product category } & \multicolumn{6}{|c|}{$\begin{array}{l}\text { The average monthly income of the household } \\
\text { (average per person) }\end{array}$} & \multicolumn{2}{|c|}{ Residence } \\
\hline & 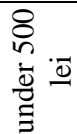 & 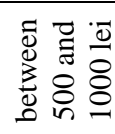 & 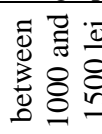 & 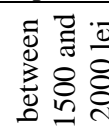 & 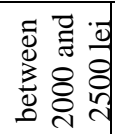 & 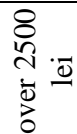 & 宽 & 乐 \\
\hline $\begin{array}{l}\text { Skin-care products (creams, } \\
\text { cleansers, masks, shaving } \\
\text { products, etc.) }\end{array}$ & 3 & 6 & 17 & 16 & 14 & 15 & 16 & 4 \\
\hline Make-up & 22 & 6 & 13 & 31 & 5 & 10 & 19 & 12 \\
\hline Perfumes & 7 & 34 & 23 & 31 & 74 & 65 & 44 & 15 \\
\hline $\begin{array}{l}\text { Hair care products (shampoo, } \\
\text { conditioner, treatment, etc.) }\end{array}$ & 21 & 17 & 8 & 1 & 0 & 0 & 5 & 17 \\
\hline $\begin{array}{l}\text { Body care products (soaps, } \\
\text { shower gels, deodorants, } \\
\text { lotions, etc.) }\end{array}$ & 48 & 38 & 38 & 19 & 7 & 10 & 15 & 52 \\
\hline Total respondents & 100 & 100 & 100 & 100 & 100 & 100 & 100 & 100 \\
\hline
\end{tabular}

* were exempted respondents who did not answer

Regarding the amount of money consumers are willing to spend monthly for the purchase of cosmetics, of the 498 respondents who provided information on this subject, most of them - 47\% - indicated a value between 50 and 100 lei. About 28\% are willing to spend less than $50 \mathrm{RON}$ and $13 \%$ between 100 and 150 lei.

The differences are observed by categories of respondents, as follows:

- With age consumers are willing to spend more money to cosmetics, most until 40 years (50\%) indicating the range of "less than 50 lei", while this range is indicated by under $15 \%$ of those over 40 years;

- $\quad$ By gender, we found slight differences, women being decided in a greater extent, to allocate more money to cosmetics;

- Depending on civil status, most people living together (54\%) are willing to spend between 50 and 100 lei per month for the purchase of cosmetics. The category of those living alone show a greater heterogeneity in terms of amounts that they are willing to allocate to cosmetic products during a month;

- As expected, higher income consumers are willing to spend more money to cosmetics, compared to those with low incomes;

- People in urban areas are also willing to allocate more money to cosmetics compared to those in rural areas.

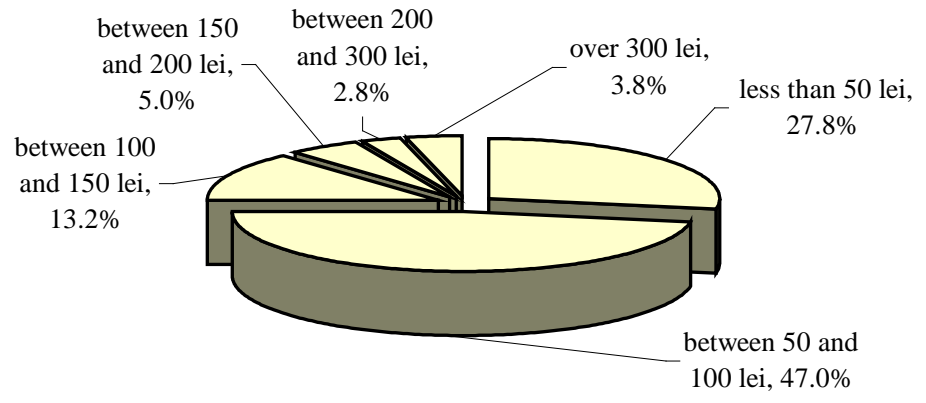

Figure 3 Structure of respondents* according to the amount of money they are willing to spend monthly for the purchase of cosmetics

* were exempted respondents who did not answer 
Table 3 Structure of respondents* according to the amount of money they are willing to spend per month to purchase cosmetics by age, gender, marital status, income and living environment (\%)

\begin{tabular}{|c|c|c|c|c|c|c|c|c|c|}
\hline \multirow[b]{2}{*}{ Monthly allowance } & \multicolumn{5}{|c|}{ Age } & \multicolumn{2}{|c|}{ Gender } & \multicolumn{2}{|c|}{$\begin{array}{c}\text { Marital } \\
\text { status }\end{array}$} \\
\hline & 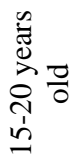 & 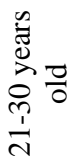 & 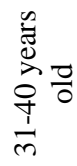 & 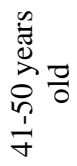 & 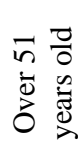 & 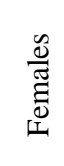 & $\frac{\mathscr{U}}{\sum^{\pi}}$ & 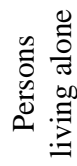 & 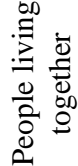 \\
\hline less than 50 lei & 51 & 55 & 50 & 11 & 14 & 25 & 31 & 30 & 24 \\
\hline between 50 and 100 lei & 34 & 33 & 37 & 57 & 49 & 47 & 48 & 34 & 54 \\
\hline between 100 and 150 lei & 14 & 8 & 7 & 17 & 17 & 16 & 10 & 17 & 11 \\
\hline between 150 and 200 lei & 0 & 4 & 3 & 7 & 4 & 5 & 5 & 7 & 4 \\
\hline between 200 and 300 lei & 0 & 0 & 1 & 1 & 13 & 2 & 4 & 5 & 2 \\
\hline over 300 lei & 0 & 0 & 2 & 6 & 4 & 5 & 2 & 7 & 2 \\
\hline Total respondents & 100 & 100 & 100 & 100 & 100 & 100 & 100 & 100 & 100 \\
\hline
\end{tabular}

Table 3 (continuation)

\begin{tabular}{|c|c|c|c|c|c|c|c|c|}
\hline \multirow[b]{2}{*}{ Monthly allowance } & \multicolumn{6}{|c|}{$\begin{array}{c}\text { The average monthly income of the } \\
\text { household (average per person) }\end{array}$} & \multicolumn{2}{|c|}{ Residence } \\
\hline & 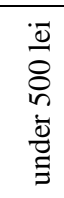 & 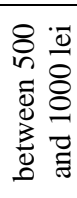 & 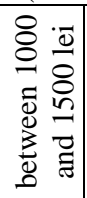 & 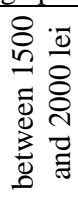 & 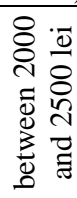 & 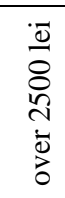 & $\begin{array}{l}\text { 苋 } \\
\text { है }\end{array}$ & 急 \\
\hline Less than 50 lei & 42 & 33 & 23 & 13 & 16 & 8 & 22 & 35 \\
\hline between 50 and 100 lei & 30 & 36 & 69 & 76 & 33 & 48 & 53 & 42 \\
\hline between 100 and 150 lei & 16 & 10 & 4 & 4 & 36 & 36 & 12 & 14 \\
\hline between 150 and 200 lei & 5 & 7 & 4 & 3 & 2 & 8 & 5 & 5 \\
\hline between 200 and 300 lei & 3 & 7 & 1 & 0 & 2 & 0 & 3 & 3 \\
\hline over 300 lei & 4 & 6 & 0 & 3 & 11 & 0 & 6 & 1 \\
\hline Total respondents & 100 & 100 & 100 & 100 & 100 & 100 & 100 & 100 \\
\hline
\end{tabular}

Referring to the importance of some of the main criteria for selecting cosmetics (shown in table 4), we note that, firstly, consumers appreciate the best quality-price options, followed by convenience in purchasing products, the nature of the ingredients (natural) and finally, brand awareness. Note that all 500 respondents expressed their views on this issue.

Significant differences are recorded in the categories of persons by considered socioeconomic and demographic criteria, namely:

- By age groups, the importance of all 4 criteria in the purchase of cosmetics is higher for older age categories. The biggest differences between young and old is registered in terms of the importance attributed to convenience in acquiring products;

- By gender, differences are found in terms of the importance attributed to the acquisition comfort and used ingredients. Thus, if more men appreciate the convenience of buying process, women are more interested in natural ingredients; 
- Depending on civil status, the importance attributed to the acquisition comfort is different, being more appreciated by those who live together. A similar situation is seen for the use of natural ingredients criterion, but differences between categories of respondents being smaller;

- In relation to household income, the biggest difference in terms of the importance given to the process of buying cosmetic products is registered for the use of natural ingredients and brand awareness, followed by convenience in purchasing, all being considered important by those with higher incomes;

- By residence, a greater importance in the purchase decision is given in urban areas compared to rural area to brand awareness and use of natural ingredients. On the other hand, compared to those in urban areas, rural respondents indicated that the most important are best quality-price option and convenience in the purchase.

Table 4 Distribution of respondents according to the importance given to some of the main selection criteria for cosmetic products on a scale from 5 (very important) to 1 (unimportant) and calculated average score for each criterion

\begin{tabular}{|c|c|c|c|c|c|c|}
\hline \multirow{2}{*}{ Criteria } & \multicolumn{5}{|c|}{ Awarded score } & \multirow{2}{*}{$\begin{array}{c}\text { Average } \\
\text { score }\end{array}$} \\
\hline & 5 & 4 & 3 & 2 & 1 & \\
\hline Best quality-price option & 325 & 168 & 7 & - & - & 4.6 \\
\hline Brand awareness & 114 & 98 & 114 & 105 & 69 & 3.2 \\
\hline $\begin{array}{l}\text { Convenience in the } \\
\text { purchase }\end{array}$ & 228 & 105 & 66 & 72 & 29 & 3.9 \\
\hline Use of natural ingredients & 158 & 159 & 74 & 84 & 25 & 3.7 \\
\hline
\end{tabular}

Table 5 Average scores calculated on a scale from 5 (very important) to 1 (unimportant) of some of the main criteria for selecting cosmetics, depending on the focus of consumer in the process of buying cosmetic products by age, sex, marital status, income and living environment

\begin{tabular}{|c|c|c|c|c|c|c|c|c|c|}
\hline \multirow[b]{2}{*}{ Criteria } & \multicolumn{5}{|c|}{ Age } & \multicolumn{2}{|c|}{ Gender } & \multicolumn{2}{|c|}{ Marital status } \\
\hline & 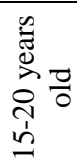 & 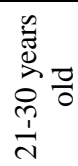 & 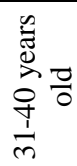 & 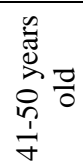 & 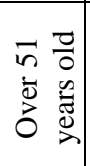 & 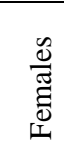 & $\frac{\mathscr{\mathscr { U }}}{\sum_{\Sigma}^{\pi}}$ & 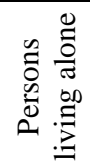 & 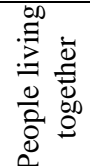 \\
\hline $\begin{array}{l}\text { Best quality-price } \\
\text { option }\end{array}$ & 3.9 & 4.5 & 4.7 & 4.6 & 4.8 & 4.8 & 4.4 & 4.6 & 4.6 \\
\hline Brand awareness & 2.1 & 1.9 & 2.7 & 3.9 & 3.5 & 3.1 & 3.3 & 3.1 & 3.3 \\
\hline $\begin{array}{l}\text { Convenience in the } \\
\text { purchase }\end{array}$ & 2.7 & 2.9 & 4.4 & 4 & 4.3 & 3.5 & 4.3 & 3.3 & 4.2 \\
\hline $\begin{array}{l}\text { Use of natural } \\
\text { ingredients }\end{array}$ & 2.8 & 2.7 & 3.3 & 4.2 & 4.1 & 4 & 3.3 & 3.4 & 3.9 \\
\hline
\end{tabular}


Table 5 (continuation)

\begin{tabular}{|c|c|c|c|c|c|c|c|c|}
\hline \multirow[b]{2}{*}{ Criteria } & \multicolumn{6}{|c|}{$\begin{array}{l}\text { The average monthly income of the } \\
\text { household (average per person) }\end{array}$} & \multicolumn{2}{|c|}{ Residence } \\
\hline & 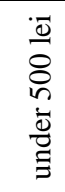 & 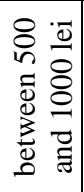 & 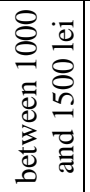 & 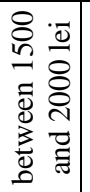 & 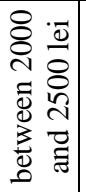 & 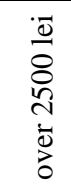 & $\begin{array}{l}\text { है } \\
\text { है }\end{array}$ & 苞 \\
\hline $\begin{array}{l}\text { Best quality-price } \\
\text { option }\end{array}$ & 4.5 & 4.1 & 4.9 & 4.8 & 4.7 & 4.5 & 4.3 & 4.9 \\
\hline Brand awareness & 2.7 & 2.5 & 3.4 & 3.9 & 4.7 & 4.6 & 3.6 & 2.8 \\
\hline $\begin{array}{c}\text { Convenience in the } \\
\text { purchase }\end{array}$ & 3.8 & 3.4 & 3.8 & 4.1 & 4.5 & 4.5 & 3.7 & 4.1 \\
\hline $\begin{array}{l}\text { Use of natural } \\
\text { ingredients }\end{array}$ & 2.8 & 3.3 & 3.8 & 4.7 & 4.7 & 4.8 & 4.1 & 3.3 \\
\hline
\end{tabular}

\section{Conclusions}

In conclusion, based on the results of exploratory research undertaken using a sample of 500 individuals, it was revealed that the most commonly purchased brand of cosmetics is Avon (over 60\% of persons who provided information on this subject), followed by Oriflame (15\%). Cosmetics for which investigated persons allocated the most money are body care products (soaps, shower gels, deodorants, lotions, etc.), followed by perfumes and makeup. Nearly half of respondents (47\%) are willing to monthly spend for cosmetics an amount between 50 and 100 lei, around 28\% under 50 lei and 13\% between 100 and 150 lei. The criteria rated as the most important in the process of buying cosmetic products are: best quality-price ratio, followed by convenience in purchasing products.

\section{References:}

Aaker, David A., V. Kumar, George S. Day (1998), Marketing research, 6 $6^{\text {th }}$ Edition, John Wiley \& Sons, Inc., New York, ş.a.

Cătoiu, Iacob, Nicolae Teodorescu (2003), Comportamentul consumatorului, Editura Uranus, București.

Cătoiu, Iacob (coordonator) (2002), Cercetări de marketing, Editura Uranus, Bucureşti.

Harja, Eugenia, Laura C. Țimiraş. (2010), Metode statistice utilizate în cercetarea de marketing, Editura Alma Mater, Bacău.

Ţimiraş, C. Laura (2007), Tendinţe în evoluţia marketingului agroalimentar în contextul extinderii Uniunii Europene, Editura EduSoft, Bacău. 